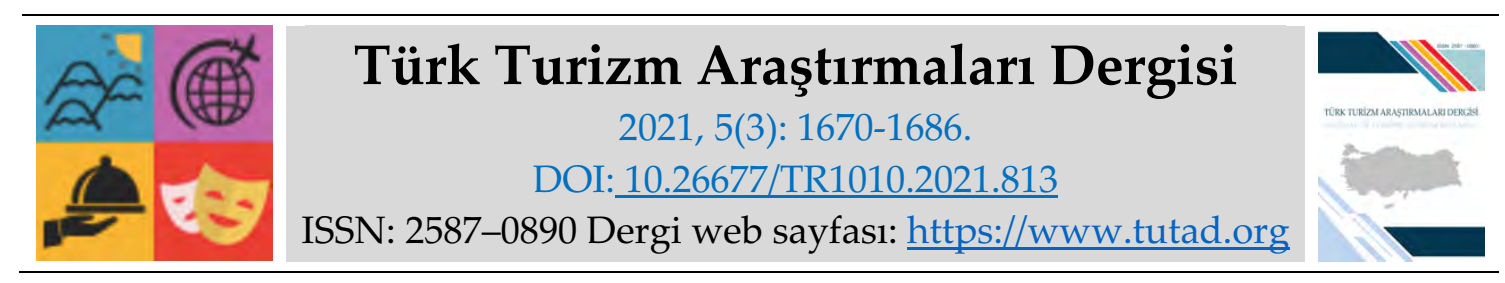

ARASTIRMA MAKALESI

\title{
Kurumsal İtibarın Yiyecek-İçecek İşletmeleri İmajı Üzerindeki Etkisinde Müşterilerin Hijyen Algılarının Rolü
}

Dr. Öğr. Üyesi Mustafa IŞKIN, Sivas Cumhuriyet Üniversitesi, Turizm Fakültesi, Sivas, e-posta: mustafaiskin@cumhuriyet.edu.tr

ORCID: https://orcid.org/0000-0002-5097-2268

\section{Öz}

Yiyecek-içecek işletmeleri için müşterilerin itibar, hijyen ve imaj algıları önemli bir yere sahiptir. Yiyecek-içecek işletmeleri uzun süreli faaliyetler sonucunda müşterilerinin zihninde, olumlu kurumsal itibar algısı sağlayabilir. Olumlu kurumsal itibar algısı sağlayan işletmelerin müşterileri, işletmeye güven duyacakları için, hijyen koşullarına ilişkin olumlu algı geliştirebilirler. Bunun yanında olumlu kurumsal itibar algısı, kısa sürede oluşan ve olumlu veya olumsuz koşullardan hızlı etkilenen işletme imajını da etkilemektedir. Bu çalışmanın amacı yukarıda belirtilen ilişkide hijyen koşullarının aracı rolünü belirlemektir. Araştırmanın evrenini yiyecek-içecek işletmelerinden hizmet alan müşteriler oluşturmaktadır. Çalışma sürecinde evrenden 527 kişi anket formunu doldurmuştur. Araştırmada nicel araştırma yaklaşımı benimsenmiştir. Bu doğrultuda anket tekniği kullanılarak veriler toplanmıştır. Elde edilen veriler process makro uygulaması kullanılarak analiz edilmiştir. Yapılan analizler sonucunda kurumsal itibar algısının, hijyen koşullarını ve işletme imajını algılamada etkili olduğu tespit edilmiştir. Ayrıca kurumsal itibar algısının işletme imajı algısı üzerindeki etkisinde hijyen koşularının aracı rolü olduğu tespit edilmiştir.

Anahtar Kelimeler: Kurumsal İtibar, Hijyen Koşulları, İşletme İmajı, Yiyecek-İçecek İşletmeleri. Makale Gönderme Tarihi: 28.06.2021

Makale Kabul Tarihi: 04.09.2021

\section{Önerilen Atıf:}

Işkın, M. (2021). Kurumsal İtibarın Yiyecek-İçecek İşletmeleri İmajı Üzerindeki Etkisinde Müşterilerin Hijyen Algılarının Rolü, Türk Turizm Araştırmaları Dergisi, 5(3): 1670-1686.

(c) 2021 Türk Turizm Araştırmaları Dergisi. 


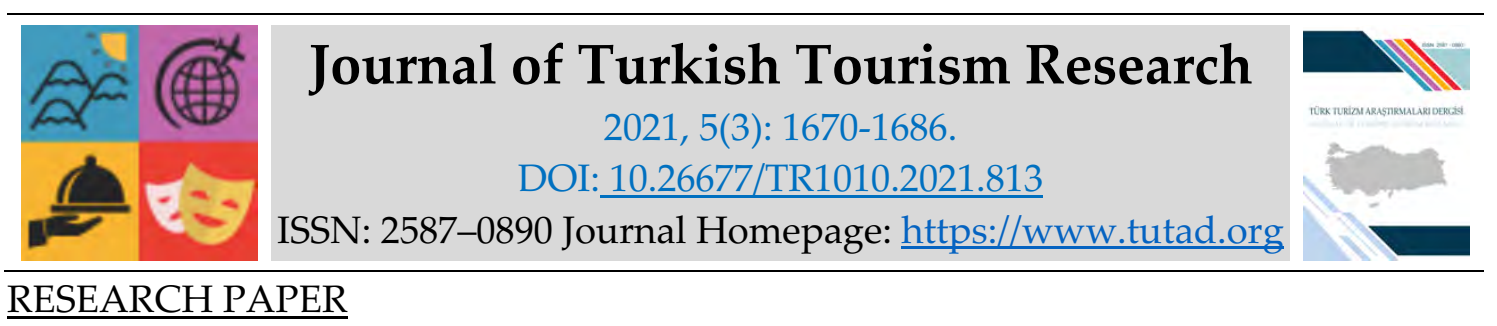

\title{
The Role of Customers' Perceptions of Hygiene in the Impact of Corporate Reputation on the Image of Food and Beverage Businesses
}

Assistant Prof. Dr. Mustafa IŞKIN, Sivas Cumhuriyet University, Faculty of Tourism, Sivas, email: mustafaiskin@cumhuriyet.edu.tr

ORCID: https://orcid.org/0000-0002-5097-2268

\begin{abstract}
Reputation, hygiene and image perceptions of customers have an important place for food and beverage businesses. Food and beverage businesses can provide a positive perception of corporate reputation in the minds of their customers as a result of long-term activities. Customers of businesses that provide a positive perception of corporate reputation can develop a positive perception of hygiene conditions as they will trust the business. In addition, the perception of positive corporate reputation also affects the image of the business, which is formed in a short time and is quickly affected by positive or negative conditions. The aim of this study is to determine the mediating role of hygiene conditions in the above-mentioned relationship. The universe of the research consists of customers who receive service from food and beverage businesses. During the study process, 527 people from the universe filled out the questionnaire. Quantitative research approach was adopted in the study. In this direction, data were collected using the questionnaire technique. The obtained data were analyzed using the process macro application. As a result of the analysis, it has been determined that the perception of corporate reputation is effective in perceiving hygiene conditions and business image. In addition, it has been determined that hygiene conditions have a mediating role in the effect of corporate reputation perception on business image perception.
\end{abstract}

Keywords: Corporate Reputation, Hygiene Conditions, Business Image, Food and Beverage Businesses.

Received: 28.06 .2021

Accepted: 04.09.2021

\section{Suggested Citation:}

Işkın, M. (2021). The Role of Customers' Perceptions of Hygiene in the Impact of Corporate Reputation on the Image of Food and Beverage Businesses, Journal of Turkish Tourism Research, 5(3): 1670-1686.

(C) 2021 Türk Turizm Araştırmaları Dergisi. 


\section{Gíriş}

Kurumsal itibar aslında işletmelere önemli avantajlar sağlayabilmektedir (Keh ve Xie, 2009: 733). Söz konusu avantajlar yiyecek-içecek işletmeleri açısından önemli yere sahiptir. Yiyecek-içecek işletmelerinde hammadde ve girdi sağlama maliyetlerinin düşürülmesinde, müşterilerin satın alama davranışlarını etkilemede, müşterilerin sadakatlerinin geliştirilmesinde ve fiyatlama konusunda esneklik sağlamada kurumsal itibarın rolünün önemli olduğu gözlemlenmektedir (Walsh ve Beatty, 2007: 128; Chang, 2013: 2). Covid 19 salgını döneminde, normalleşme sürecinde ve normal koşulların hakim olduğu dönemde de kurumsal itibarın avantajları işletmeler için önemli rekabet avantajı sağlayacak bir role sahiptir denilebilir. Özellikle yaşanabilecek olumsuzlukların, işletme imajına etkilerinin azaltılması için kurumsal itibar etkili olabilmektedir (Barnett vd., 2006: 27). Söz konusu olumsuzluklar arasında hijyen koşullarında yaşanabilecek aksaklıklarda yer almaktadır. Kurumsal itibar bileşenleri, yiyecek-içecek işletmelerinde hijyen koşullarının iyileştirilmesini de kapsadığı için, söz konusu olumsuzlukların işletme imajında olumsuz yansımalara neden olmasını önleyebilir (Gray vd., 1998: 695).

Yiyecek-İçecek işletmelerinde hijyen uygulamalarını ve hijyene verilen önemin, işletme müşterilerinin söz konusu yiyecek-içecek işletmelerini tercih etmeleri açısından önemli bir role sahip olduğu söylenebilir. Çünkü restoran işletmelerinin hijyene verdikleri önem müşteriler tarafından gözlemlenmektedir. Herhangi bir restoranda çok lezzetli yemekler yapılıyor olsa dahi söz konusu restoranda hijyen kurallarına uyulmadığ 1 içim müşteriler tarafından tercih edilmeyebilmektedir (Ho vd., 2017: 2). Özellikle Covid-19 sürecinde hijyen algısı müşterilerin yiyecek-içecek işletmeleri tercihlerinde daha etkin rol oynayabilmektedir. Müşteriler yiyecekiçecek işletmelerine gittiklerinde karşılaştıkları mekanın, kullanılan malzemenin, sunulan yemeklerin, sunulan hizmetlerin ve hizmeti sunan çalışanların hijyenik olmalarını önemseyebilmektelerdir. Çünkü müşteri yiyecek-içecek işletmesine gittiğinde mekanın temizliği iyi değilse, duvarlar ve zemin kirliyse, masalar bakımsızsa ve temiz değilse, kullanılan araç ve gereçler steril değilse, sunulan yemekler hijyenik görünmüyorsa, yemeklerin hazırlanması ve sunumunu gerçekleştiren çalışanların görünümleri ve kıyafetleri hijyenik görünmüyorsa restoranın hijyenine ilişkin olumsuz algı geliştirebilir (Läikkö-Roto ve Nevas, 2014: 66). Yiyecekiçecek işletmelerinin hijyen uygulamaları ve hijyene verdikleri önem derecesinin müşterilerde oluşturduğu algı müşterinin restoran işletmesine bakış açısını etkileyebilmektedir.

Yiyecek-içecek işletmesine ilişkin hijyen algısı oluşan müşterilerin, söz konusu algı doğrultusunda yiyecek-içecek işletmesine ilişkin işletme imajı algıları şekillenebilmektedir. İşletme imajının şekillenmesinde müşterilerin hijyen algılarının yanında, farklı değişkenlerin rolü olduğu söylenebilir (Jin ve Leslie, 2009: 237). Ancak özellikle Covid-19 küresel salgını sürecinde müşterilerin hijyen algılarının müşterilerin işletme imajı algıları üzerinde etkili ve önemli bir değişken halini aldığı söylenebilir. Yukarıda belirtildiği üzere yiyecek-içecek işletmeleri müşterilerinin hijyen algısı kurumsal itibarın belirleyicileri arasındadır. Bunun yanında müşterilerin hijyen algısı yiyecek içecek işletmelerinin işletme imajları üzerinde de etkiye sahiptir denilebilir. Çünkü özellikle yiyecek-içecek işletmelerinde hijyen algısı işletmenin imajını doğrudan etkilemektedir. Hijyen koşullarının sağlanmadığı işletmelere karşı müşterilerin talepleri çok esnek bir şekilde olumsuz yönde değişebilmektedir (Han vd., 2015: 86). Yiyecekiçecek işletmelerinin sunmuş olduğu hizmetin karakteristik özelliklerinden olan talep esnekliği, yiyecek içecek işletmelerinin imajlarını ve kurumsal itibarlarını yönetmeleri konusunda önemli bir baskı unsuru olarak görülebilir. Hizmetin esnek talep özelliği yiyecek-içecek işletmelerinde hijyene daha fazla önem verilmesini gerektirmektedir. Nitekim yiyecek-içecek işletmelerinin değerlendirildiği çevrimiçi ortamlarda hijyene ilişkin değerlendirmelerin yüksek düzeyde olduğu görülmektedir. Hijyenin böylesine önemli bir role sahip olduğu yiyecek içecek 
işletmelerinde, kurumsal itibar ve işletme imajının yönetilmesinde hijyen değişkeninin rolünün önemi iyi anlaşılmalıdır.

Bu doğrultuda çalışma kurumsal itibarın işletme imajına etkisinde müşterilerin hijyen algılarının aracı rolünün düzeyinin belirlenmesi üzerine odaklanmaktadır. Çalışmada covid-19 salgını sürecinde önemi daha iyi anlaşılan hijyene ilişkin müşteri algısının, kurumsal itibarın ve işletme imajı arasındaki etkisinde aracı rolü tespit edilmeye çalışılacaktır.

\section{KAVRAMSAL ÇERÇEVE}

Kurumsal itibar işletme imajının belirleyicileri arasında yer almaktadır (Nguyen ve Leblanc, 2001: 228). Kurumsal itibara ilişkin farklı bakış açıları mevcuttur. Ancak kurumsal imajın belirleyicisi olan kurumsal itibar, işletmenin sahip olduğu değerlerle ilgilidir. Kurumsal itibarın oluşması sadece işletmelerin faaliyetlerine bağlı değildir. İşletmelerin faaliyetlerinin paydaşlar tarafından algılanması kurumsal itibar için daha önemlidir. Birçok işletme paydaşlarına yönelik sözler verebilir, onlara güvenceler sunabilir ve paydaşlarının güvenlerini sağlamaya çalışabilir. Ancak bu faaliyetler ve davranışların devamlılığı önemlidir (Potgieter ve Doubell, 2020: 108-109). Bu faaliyetlerin işletme içerisinde kabullenilmesi ve örgüt kültürünün parçası haline getirilmesi sonucunda kurumsal itibar sağlanabilir. İşletmeler için önemli bir yere sahip olan kurumsal itibar kavramına ilişkin bilim insanları tarafından ileri sürülmüş birçok tanım mevcuttur. Örgüt teorisi açısından kurumsal itibar, işletme faaliyetlerinin paydaşlar tarafından bilişsel olarak değerlendirilmesi sonucunda ortaya çıkan ve işletmeyi paydaş zihninde temsil eden yansıma olarak tanımlanmaktadır. Bunun yanında çeşitli alanlara ilişkin kurumsal itibar tanımları da bulunmaktadır. Söz konusu alanlar içerisinden bu çalışma ile ilgili olan strateji alanına ilişkin tanımda ise kurumsal itibar, işletmelerin rekabet avantajı sağlamalarında önemli bir yere sahip olan ve diğer işletmelerin taklit etmelerinin, ikamesini bulmalarının zor olduğu maddi varlık olarak tanımlanmıştır (Hu vd., 2020: 1127). Ayrıca iletişim alanına ilişkin tanımda, kurumsal itibar, işletmelerin etkileşim içerisinde olduğu birçok paydaş ile kurumsal özelliklerini yansıtarak kurmuş oldukları ilişkiler olarak tanımlanmaktadır (Fombrun vd., 2000: 243). Aslında söz konusu tanımların tamamında paydaşların zihninde işletmenin, faaliyetlerine ve vermiş oldukları sözlere ilişkin oluşan bilişsel yansımanın varlığı vurgulanmaktadır.

Kurumsal itibara ilişkin teoriler incelendiğinde kurumsal itibarın çeşitli bileşenleri olduğu görülmektedir. Söz konusu bileşenler kurumsal itibarın hangi unsurlara göre şekillendiği hakkında fikir edinmek için önemlidir. Şekil 1'de görüldügü üzere kurumsal çekicilik kurumsal itibar bileşenleri arasında yer almaktadır. Kurumsal çekicilik, işletmenin paydaşlar tarafından ne düzeyde beğenildiği ve saygınlık düzeyine ilişkin bileşendir. Kurumsal çekicilik bileşeni işletmelerin beğenilme ve saygınlığının değerlendirildiği bileşen olarak kabul edilebilir (Chun, 2005: 94; Agarwal vd., 2015: 486). Kurumsal çekicilikten sonra, bu çalışma ile ilgili en önemli kurumsal itibar bileşeni diyebileceğimiz ürünler ve hizmetler gelmektedir. Bu bileşen kapsamında ürünlerin veya hizmetlerin kalitesi, yenilikçilik düzeyleri ve güvenilirlikleri yer almaktadır. Kurumsal itibarın diğer bir bileşeni ise paydaşlarına önemli mesajlar veren finansal performanstır (Javed vd., 2020: 2692-2693). Birçok paydaş işletmelerin finansal performansını önemsemektedir. Diğer yandan kurumsal itibarın bileşenlerinden biri de vizyon ve liderliktir. Paydaşların işletmelere ilişkin itibar algısı geliştirirlerken, işletmede vizyon sahibi liderlerin olup olmadığını değerlendirdikleri görülmektedir (Walsh vd., 2009: 188). Başka bir kurumsal itibar bileşeni ise çalışma çevresi veya ortamıdır. İşletmelerin ne kadar iyi yönetildiği, işletmede çalışma ikliminin nasıl olduğu ve bu çalışma içinde önemli bir yere sahip olan çalışanların kalitesi, yetkinlikleri ve dürüstlükleri gibi unsurlar bu bileşen kapsamında değerlendirilmektedir (Singh ve Misra, 2021: 102). Diğer bir kurumsal itibar bileşeni ise sosyal sorumluluk bileşenidir. Sosyal 
sorumluluk bileşeninde paydaşların, işletmenin toplum ve çalışanları ile ilişkilerinde nasıl hareket ettiğine ilişkin değerlendirmeler yaptıkları değerlendirilmektedir (Islam vd., 2021: 123124). İşletmenin faaliyet gösterdiği ve ilişkili olduğu toplumun ihtiyaçlarını ne derecede önemsediği, söz konusu ihtiyaçlara ilişkin çözümler ve projeler geliştirip geliştirmediği bu bileşen kapsamında değerlendirilmektedir (Alrubaiee, 2017: 105-106; Sánchez-Torné vd., 2020: 2693). Kurumsal itibar bileşenlerinin her birinin kurumsal itibarın oluşmasında etkisi bulunmaktadır. Söz konusu bileşenlerin etkileri sektörden sektöre farklılık gösterebilmektedir. Örneğin yiyecek içecek işletmelerinde ürünlerin veya hizmetlerin güvenilirliği daha fazla ön plana çıkarken, teknoloji üreten bir işletme için inovasyon daha ön planda olabilmektedir. Kurumsal itibara ilişkin yapılacak değerlendirmelerde bu ayrıntıya dikkat etmek gerekir.

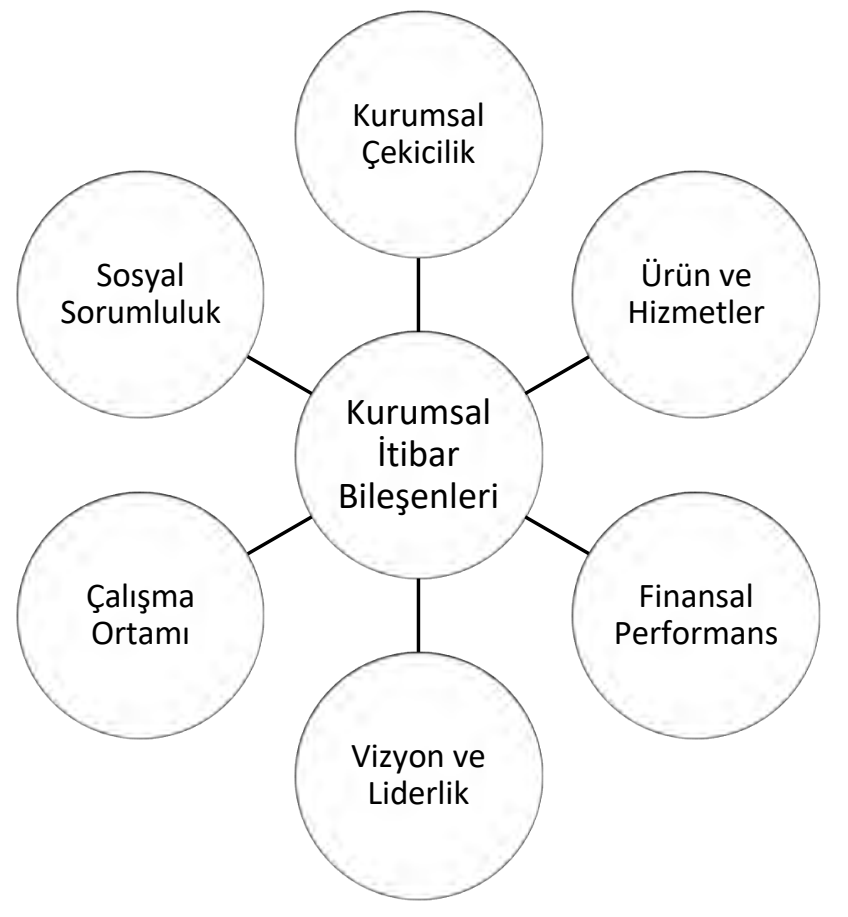

Şekil 1. Kurumsal İtibar Bileşenleri

Kaynak: Fombrun ve Gardberg, 2000: 14

Kurumsal itibarın bileşenleri içerisinde yer alan ürünler ve hizmetler kapsamında değerlendirilebilecek olan, çalışmanın değişkenlerinden hijyene ilişkin bu kısımda teorik değerlendirme yerinde olacaktır. Günümüzde hijyen geçmişe göre daha önemli hale gelmiştir denilebilir. Çünkü Covid-19 küresel salgını nedeniyle insanlar hijyene daha fazla dikkat eder hale gelmişlerdir. Yiyecek-içecek veya konaklama işletmelerinin tercihinde de işletmelerin hijyene vermiş oldukları önem önemli bir belirleyici halini almıştır diyebiliriz. Çünkü insanlar artık sağlıklarına covid-19 küresel salgınının öncesine oranla daha fazla önem göstermektelerdir. Artık birçok yiyecek-içecek işletmelerine ilişkin değerlendirmelerin yapıldığı online kanallarda, hijyene ilişkin değerlendirmelerin sayısının artığı gözlemlenebilir. Yiyecek-içecek işletmelerinin tercih edilmeleri konusunda önemli bir belirleyici konumuna gelen hijyen kavramı, temiz, sağlıklı ve insanların gönül rahatllğıyla tüketebilecekleri ürün veya hizmet üretimi süreçlerinin yürütülmesini ifade etmektedir (Walsh vd., 2006: 414; Jin ve Leslie, 2009: 237). Burada önemli olan unsur, söz konusu ürün veya hizmetlerinin üretilmesinde yukarıda belirtilen unsurlara dikkat edilmesidir. Yiyecek içecek işletmelerinde, müşterilere sunulacak ürünlerin sağlıklı, temiz, bozulmamış ve temiz araç-gereçlerle işlenmiş olması hijyenin sağlanması için önemlidir. Ayrıca tüketime hazır ürünlerin sunulması sürecinde yer alan mobilyalar, yiyecek-içecek işletmesinin 
fiziki koşulları, çalışanların kişisel sağlık durumu ve hijyenleri ile havalandırma kalitesi de hijyenin sağlanması için önemli faktörler arasında yer almaktalardır. Genel olarak yiyecek-içecek işletmelerinde hijyeni, işletmenin fiziksel hijyeni, personel hijyeni, kullanılan araç ve gereçlerin hijyeni ile yiyecek ve içeceklerin hijyeni olarak dört kategoriye ayırabiliriz (Denizer, 2003: 203; Sökmen, 2001: 16; Soylu ve Taştan, 2020: 94-96). Yiyecek-içecek işletmelerinde hijyen koşullarının sağlanması diğer işletmelere oranla daha önemli bir yere sahiptir. Çünkü yiyecek-içecek işletmelerinde üretilen gıda ürünleri doğrudan müşteriler tarafından tüketilmektedir. Diğer işletmelerde olduğu gibi müşterilerin aldıkları ürünleri temizleme ve muhafaza etme olanakları yoktur. Burada inisiyatif önemli ölçüde işletme ve işletmenin çalışanlardadır. Bu nedenle turizm işletmelerinde yaşanabilecek hijyen sorunları, işletmenin birçok çıktısını, bu çıktılara olan talebi, işletmenin itibarını ve imajını etkileyecektir.

İşletmelerin imajı işletmenin tek başına göstereceği çabalarla oluşabilecek bir unsur değildir. İşletmelerin faaliyetlerinin veya üretmiş oldukları ürün veya hizmetlerin paydaşların zihnindeki yansıması işletme imajı olarak tanımlanabilir (Dichter, 1985: 75; Dowling, 1986: 110). İşletme imajı, işletmeye özgü olan ve işletmenin faaliyetleri sonucunda oluşan, işletmeyi temsil eden bütün görsel ögeler, söylenen sözler, sözel dokümanlar ve davranışları kapsayan bir kavram olarak tanımlanabilir (Andreassen ve Lindestad, 1998: 84; Howard, 1998). Bu tanımda belirtildiği üzere aslında işletme imajı, işletmelerin yaptıkları veya yapmadıkları şeylerin müşteriler tarafından nasıl algılandığı ile ilgili olduğu görülmektedir. İşletme imajı, çeşitli faktörlerden etkilenen ve söz konusu faktörlerin, müşteriler tarafından algılanma biçimine göre şekillenen bir unsur olarak kabul edilebilir (Amini vd., 2012: 194). İşletme imajının şekillenmesinde etkili olan çeşitli faktörler bulunmaktadır. Söz konusu faktörler, çalışanların paydaşlara karşı yaklaşımı ve işleri ile ilgili davranış şekilleri, işletmenin kimliğini yansıtan unsurlar, işletmede liderlik rolünü üstlenen kişilerin yaklaşımları ve davranışları, müşterilerin memnuniyet düzeyleri, endüstride yer alan işletmelerle ilişkilerin durumu ve işletmenin fiziksel görünüşü olarak sırlanabilir (Schmitt vd., 1995; Peltekoğlu, 2012: 583). Görüldüğü üzere kurumsal imajı etkileyen birçok faktör bulunmaktadır. İşletmelerin paydaşların zihnindeki yansımalarını olumlu konuma taşımaları veya olumlu konumda tutabilmeleri işletmelerin yukarıda belirtilen faktörlere önem vermeleri ve faaliyetlerini bu doğrultuda gerçekleştirmeleri ile mümkün olabilecektir.

Söz konusu faktörlerin bir kısmı aslında kurumsal itibar üzerinde de etkisi olan unsurladır. Bu nedenle kurumsal itibarın kurumsal imajın oluşmasında etkisi olduğu söylenebilir. Burada dikkate alınması gereken nokta, kurumsal itibarın uzun bir süreç sonunda, paydaşların işletmenin geneline ilişkin elde etmiş olduğu izlenimleri yorumlaması sonucunda ortaya çıkıyor olmasıdır. Ancak kurumsal imaj kısa süre içerisinde şekillenebilmektedir. Kurumsal itibar uzun bir süreç ve yorumlama sonucunda ortaya çıktığı için değişmesi ve olumsuzluklardan hızlı etkilenmesi kolay değildir. Ancak imaj olumsuzluklardan veya olumlu faaliyetlerden hızlı bir şekilde etkilenebilmektedir.

Bu çalışmada öncelikle, uzun bir süreç sonucunda, müşterilerin işletme ile ilgili izlenimlerini zihinlerinde yorumlayarak oluşturmuş oldukları kurumsal itibar değişkeninin, kısa sürede şekillenebilen ve olumlu veya olumsuz unsurlardan çok çabuk etkilenebilen işletme imajının oluşumunda etkisinin (Hu vd., 2020: 1126) var olup olmadığı tespit edilmeye çalışılacaktır. Bu doğrultuda ilk olarak aşağıdaki hipotez oluşturulmuştur.

"H1: Müşterilerin yiyecek-içecek işletmelerinin kurumsal itibarlarına ilişkin algı düzeylerinin, işletme imajı algıları üzerinde etkisi vardır."

Kurumsal itibar işletmelerin faaliyetlerine ilişkin paydaşların zihninde uzun sürede ortaya çıkan bir olgudur. Kurumsal itibar işletmenin faaliyetleri sonucunda ortaya çıkan, ancak sadece işletmelerin faaliyetlerine bağlı olmayan, paydaşların algılamaları ve yorumlamalarına bağlı 
olarak ortaya çıkan bir karaktere sahiptir. Ancak diğer taraftan işletmenin kurumsal itibara sahip olması, işletmenin faaliyetlerinin ve uygulamalarının da olumlu algılanmasında etkili olmaktadır. Bu kapsamda bir yiyecek içecek işletmesinin kurumsal itibar düzeyi, söz konusu işletmenin hijyen koşullarının algılanmasında etkili olabilmektedir. Kurumsal itibar düzeyi yüksek bir işletme hijyen koşullarına yüksek düzeyde önem vermese dahi, kurumsal itibar düzeyinin yüksek olmasına bağlı olarak, müşterilerin hijyen koşullarını algılanmalarında olumlu etkiye sahip olabilir (Jin ve Leslie, 2009: 237). Bu doğrultuda aşağıdaki hipotez oluşturulmuştur.

"H2: Müşterilerin yiyecek-içecek işletmelerine ilişkin kurumsal itibar algı düzeylerinin, müşterilerin işletmelerin hijyen koşullarına ilişkin algı düzeyleri üzerinde etkisi vardır."

İşletme imajı kısa süreli faaliyet ve uygulamalarla değişebilen ve oluşması için çok uzun süre gerekmeyen bir olgudur. Bu nedenle özellikle Covid-19 küresel salgını döneminde hijyen koşullarına ilişkin uygulamalar yiyecek-içecek işletmelerinin imajı üzerinde etkili olabilmektedir (Gray ve Balmer, 1998: 696). Bu doğrultuda hijyen koşullarına ilişkin müşteri algısının işletmenin imajını etkilediği varsayımına dayanan aşağıdaki hipotez oluşturulmuştur.

"H3: Müşterilerin yiyecek işletmelerinin hijyen koşullarına ilişkin algularının işletmelerin imajları üzerinde etkisi vardır."

Daha sonra kurumsal itibar düzeyinin, hijyen aracı değişkeni üzerinden işletme imajı üzerine etkisi olup olmadığı tespit edilmeye çalışılmıştır. Burada önemli olan nokta, işletmelerin kurumsal itibar algı düzeylerinin, işletme imajında farklılaşma sağlayabilme potansiyeline sahip olan hijyen değişkeni aracılığıyla işleme imajını etkileyip etkilemediğinin belirlenmesidir. Hijyen değişkeni kısa sürede değişebilme potansiyeline sahip işletme imajını etkileyebilir. Hijyen koşulları sağlanırsa müşterilerin işletmeye ilişkin imaj algıları olumlu yönde etkilenir ancak hijyen koşullarında sorunlar varsa imaj algıları olumsuz yönde etkilenecektir (Gray ve Balmer, 1998: 696; Jin ve Leslie, 2009: 237; Hu vd., 2020: 1126). Ancak bu çalışmada kurumsal itibarın işletmenin imajına etkisinde hijyen koşullarının aracı rolü tespit edilmeye çalışılmıştır. Bunun nedeni kurumsal itibara ilişkin müşteri algısının işletmenin imajını etkilemesinde hijyen koşullarının rolüne ilişkin değerlendirme yapılmak istenmesidir. Müşterilerde zamanla oluşan kurumsal itibar algısının, müşterilerin işletmeye ilişkin imaj algıları üzerinde etkisinde hijyen koşulları aracı rolünü tespit etmek için aşağıdaki hipotez oluşturulmuştur.

"H4: Müşterilerin yiyecek-içecek işletmelerine ilişkin kurumsal itibar algı düzeylerinin, müşterilerin işletmeye ilişkin imaj algıları üzerinde etkisinde hijyen koşullarının aracı rolü vardır."

Yukarıdaki hipotezler doğrultusunda Şekil 1'de yer alan araştırma modeli oluşturulmuştur. Sonraki kısımlarda yukarıda teorik altyapıya dayandırılarak oluşturulmuş hipotezler doğrultusunda araştırma sürecinde elde edilen verilerin analizi gerçekleştirilecektir. Ayrıca analizler sonrasında değerlendirilmeler yapılarak, araştırma değişkenlerinin arasındaki etkiler daha anlaşılır bir şekilde ortaya konulmaya çalışılacaktır. 


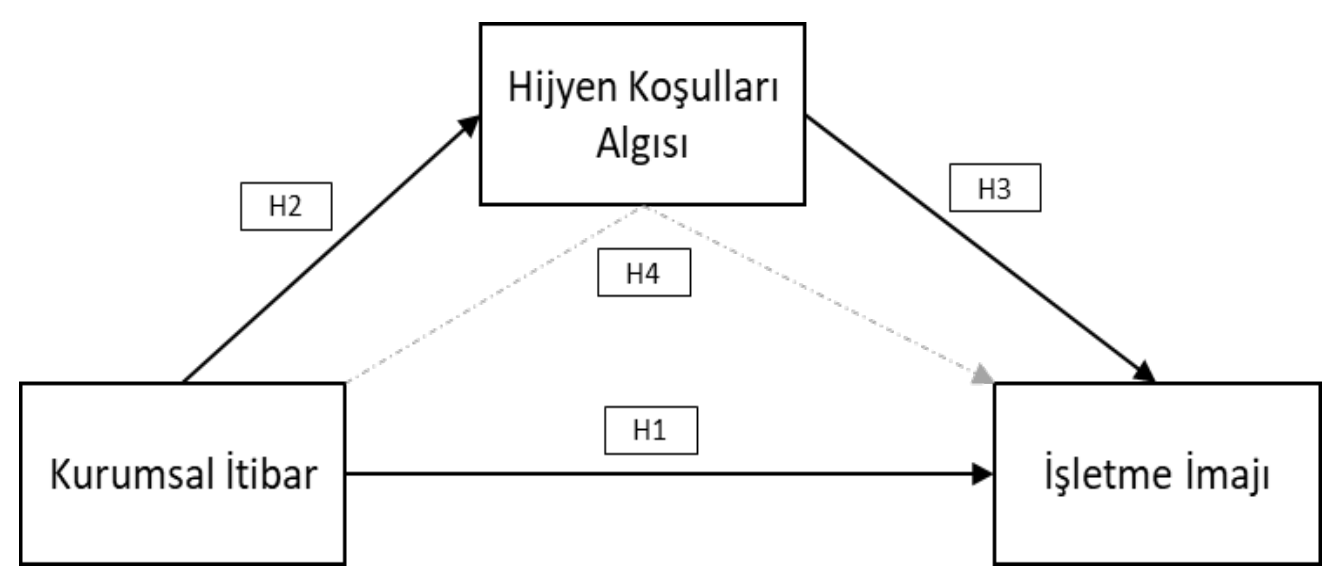

Şekil 1. Araştırma Modeli

\section{YÖNTEM}

Çalışmanın temel amacı kurumsal itibar bağımsız değişkeninin, işletme imajı bağımlı değişkeni üzerinde etkisinde hijyen koşulları aracı değişkeninin rolünü belirlemektir. Bu doğrultuda değişkenlerin arasındaki ilişkilerin ve etkileşimin keşfine arasındaki ilişkilerin ve etkileşimin keşfine yönelik olarak, deneysel olmayan araştırma yaklaşımı benimsenmiştir. Deneysel olmayan araştırma yaklaşımı kapsamında, ilişkileri ve etkileri tespit etmek için ilişkisel deneysel olmayan araştırma yaklaşımının alt yaklaşımlarından olan ilişkisel yaklaşım benimsenmiştir. İlişkisel yaklaşım kapsamında ise çıarımsal ilişki istatistiklerinden yararlanılmıştır. Demografik verilerin analizinde ise betimsel araştırma yaklaşımı kapsamındaki betimsel istatistiklerden yararlanılmıştır (Gliner vd., 2015: 46).

Araştırmada veri toplamak için anket formu oluşturulmuş ve oluşturulan form kullanılmıştır. Anket formu demografik özelliklerin ve aralık ölçeklerinin yer aldığı iki kısımdan oluşmuştur (Karagöz, 2017: 10). Anket formunda yer alan demografik özellikler çalışmanın uygulama alanına göre belirlenmiştir. Aralık ölçeklerinin yer aldığı kısımda ise, kurumsal itibarı ölçmek için, Fombrun ve arkadaşlarının (2000) oluşturmuş oldukları kurumsal itibar ölçeği (ör. Bu işletmeye güveniyorum) değişiklik yapmadan, işletme imajını ölçmek için ise Akdu (2017) tarafından Bayol (2000) ile Lebnac ve Nguyen'den (1996) uyarlanan ölçek (ör. Hizmet aldığım otel söyledikleri ve yaptıklarıyla güvenilebilirdir.) değişlik yapılmadan kullanılmıştır. Hijyen koşullarına ilişkin ölçek ise araştırma kapsamında oluşturulmuştur. Öncelikle literatür taranması yapılmış, literatür taraması sonrasında bir çerçeve çıkarılmış ve uzmanlardan görüş alınarak ölçek oluşturulmuştur. Oluşturulan ölçek ön uygulama ile test edilmiştir. Ön test sonrasında yapılan geçerlilik, güvenilirlik ve faktör analizleri sonucunda 40 ifadeden oluşan ölçekten 3 ifade çıkarılmıştır. Çalışmada söz konusu 37 ifadeden oluşan ölçek kullanılmıştır. Anket formunun ikinci kısmında yer alan değişkenlerin ölçülmesi için, aralık ölçeklerinden 5 aralıklı Likert ölçeği tercih edilmiştir.

Araştırmanın evrenini yiyecek-içecek işletmelerinden hizmet alan müşteriler oluşturmaktadır. Söz konusu müşterilerin sayısına ilişkin veri bulunmadığı için örneklem sayısı belirlenirken yeterli olacak en az örneklem sayısı olan 384 sayısı örneklem sayısı dikkate alınmıştır (Can, 2019: 29: Büyüköztürk, 2010: 8). Kolayda örnekleme kapsamında basılı olarak 400 anket dağıtılmıştır. Ayrıca online kanallar kullanılarak anket formu müşterilere dağıtılmıştır. Toplamda 527 adet anket formunun dönüşü sağlanmıştır.

Dönüş sağlanan anket formlarından elde edilen verilerle öncelikle demografik özelliklere ilişkin betimsel çıkarımlar yapabilmek için frekans ve yüzde analizi uygulanmıştır. Araştırma modelinde yer alan değişkenlere ilişkin ölçeklerin alt boyutların belirlemek ve ifadelerin alt boyutlara taşıdıkları yükleri belirlemek için açıklayıcı faktör analizi, ölçeklerin geçerlilik 
düzeylerini tespit etmek için doğrulayıcı faktör analizi yapılmıştır. Araştırma modelinin test edilmesi için, aracılık modellerinin analizinde kullanılan çă̆daş yaklaşım olarak ifade edilen bootstrap testi uygulanmıştır.

\section{BULGULAR}

Çalışmanın bu kısmında öncellikle çalışma kapsamında oluşturulan anket formunu cevaplayan katılımcılara ilişkin betimsel analiz sonuçlarına yer verilecektir. Katılımcıların demografik özelliklerine ilişkin bulgularda, katılımcıların \%68,7'sinin erkek, \%79,8'inin asgari ücretin üzerinde gelire sahip, \%66, '́ünün evli oldukları dikkat çekmektedir. Eğitim durumuna ilişkin bulgularda lise düzeyi mezuniyet derecesine sahip katılımcıların yüzdesinin $\% 28,3$, lisans düzeyi mezuniyet derecesine sahip olanların yüzdesinin benzer şekilde $\% 28,7$ olduğu tespit edilmiştir. Yaş dağılımına ilişkin sonuçlara bakıldığında ise 31-40 yaş aralığındaki katılımcılarının sayısının $(\% 25,8)$ diğer yaş guruplarına göre fazla olduğu görülmektedir.

Tablo 1. Katılımcıların Demografik Özelliklerine İlişkin Betimleyici Analiz Sonuçları

\begin{tabular}{|c|c|c|c|c|c|c|c|}
\hline Cinsiyet & & $N$ & $\%$ & Gelir Durumu & & $N$ & $\%$ \\
\hline Kadın & & 165 & 31,3 & 2825 ve alt1 & & 106 & 20,1 \\
\hline \multirow[t]{2}{*}{ Erkek } & & 362 & 68,7 & $2826-5000$ & & 251 & 47,6 \\
\hline & Toplam & 527 & 100 & $5001-7500$ & & 84 & 15,9 \\
\hline Medeni Durum & & $N$ & $\%$ & $7501-10000$ & & 61 & 11,6 \\
\hline Evli & & 350 & 66,4 & 10001 ve üzeri & & 35 & 4,7 \\
\hline \multirow[t]{2}{*}{ Bekar } & & 177 & 33,6 & & Toplam & 527 & 100 \\
\hline & Toplam & 527 & 100 & Yaş & & $N$ & $\%$ \\
\hline Ĕ̈itim Durumu & & $N$ & $\%$ & 20 yaş ve altı & & 97 & 18,4 \\
\hline İlk Öğretim & & 128 & 24,3 & $21-30$ & & 103 & 19,5 \\
\hline Lise & & 149 & 28,3 & $31-40$ & & 136 & 25,8 \\
\hline Ön Lisans & & 53 & 10,1 & $41-50$ & & 82 & 15,6 \\
\hline Lisans & & 151 & 28,7 & $51-60$ & & 73 & 13,9 \\
\hline Yüksek Lisans & & 37 & 7,0 & $61-65$ & & 24 & 4,6 \\
\hline Doktora & & 9 & 1,7 & 65 ve üzeri & & 12 & 2,3 \\
\hline & Toplam & 527 & 100 & Toplam & & 527 & 100 \\
\hline
\end{tabular}

Araştırmada kullanılan ölçekte yer alan ifadelerin ölçülmek istenen değişkene taşıdıkları yükleri tespit etmek ve alt boyutu olan değişkenlerin alt boyutlarına yük taşıyan ifadeleri belirlemek için açıklayıcı faktör analizi yapılmıştır. Açıklayıcı faktör analizine ilişkin sonuçlar Tablo 2'de verilmiştir. 
Tablo 2. Araştırmada Kullanılan Ölçeklere Ait Açıklayıcı Faktör Analizi Sonuçları

\begin{tabular}{|c|c|c|c|c|c|}
\hline $\begin{array}{l}\text { Ana } \\
\text { Değişken }\end{array}$ & Alt Boyut & İfade & $\begin{array}{l}\text { Faktör } \\
\text { Yükü }\end{array}$ & $\begin{array}{l}\text { Cronbach's Alpha } \\
\text { Değeri }\end{array}$ & $\begin{array}{l}\text { KMO ve Barlett } \\
\text { Testi Sonuçları }\end{array}$ \\
\hline \multirow{20}{*}{$\begin{array}{c}\text { Kurumsal } \\
\text { İtibar }\end{array}$} & \multirow{3}{*}{$\begin{array}{l}\text { Kurumsal } \\
\text { Çekicilik }\end{array}$} & İtibar 1 & ,852 & \multirow{20}{*}{ Değeri } & \multirow{20}{*}{$\begin{array}{l}, 867 \\
\text { Sig. , } 000\end{array}$} \\
\hline & & İtibar 2 & 855 & & \\
\hline & & İtibar 3 & ,761 & & \\
\hline & \multirow{4}{*}{$\begin{array}{l}\text { Ürün ve } \\
\text { Hizmetler }\end{array}$} & İtibar 4 & ,924 & & \\
\hline & & İtibar 5 & 624 & & \\
\hline & & İtibar 6 & 841 & & \\
\hline & & İtibar 7 & 876 & & \\
\hline & \multirow{3}{*}{$\begin{array}{l}\text { Vizyon ve } \\
\text { Liderlik }\end{array}$} & İtibar 8 & 826 & & \\
\hline & & İtibar 9 & 671 & & \\
\hline & & İtibar 10 & ,791 & & \\
\hline & \multirow{3}{*}{ Çalışma Ortamı } & İtibar 11 & ,795 & & \\
\hline & & İtibar 12 & 836 & & \\
\hline & & İtibar 13 & ,784 & & \\
\hline & \multirow{3}{*}{$\begin{array}{c}\text { Sosyal } \\
\text { Sorumluluk }\end{array}$} & İtibar 14 & 897 & & \\
\hline & & İtibar 15 & ,913 & & \\
\hline & & İtibar 16 & ,761 & & \\
\hline & \multirow{4}{*}{$\begin{array}{l}\text { Finansal } \\
\text { Performans }\end{array}$} & İtibar 17 & ,784 & & \\
\hline & & İtibar 18 & 872 & & \\
\hline & & İtibar 19 & 781 & & \\
\hline & & İtibar 20 & 816 & & \\
\hline \multirow{6}{*}{$\begin{array}{l}\text { İşletme } \\
\text { İmajı }\end{array}$} & \multirow{6}{*}{ İşletme İmajı } & İmaj 1 & ,752 & \multirow{6}{*}{0,875} & \multirow{6}{*}{$\begin{array}{c}, 895 \\
\text { Sig. , } 000\end{array}$} \\
\hline & & İmaj 2 & 864 & & \\
\hline & & İmaj 3 & 823 & & \\
\hline & & İmaj 4 & ,916 & & \\
\hline & & İmaj 5 & 737 & & \\
\hline & & İmaj 6 &, 885 & & \\
\hline \multirow{34}{*}{$\begin{array}{l}\text { Hijyen } \\
\text { Koşulları }\end{array}$} & \multirow{11}{*}{$\begin{array}{c}\text { Fiziksel (Mekan) } \\
\text { Hijyeni }\end{array}$} & Hijyen1 & 832 & \multirow{34}{*}{0,856} & \\
\hline & & Hijyen2 & 846 & & \\
\hline & & Hijyen3 & ,794 & & \\
\hline & & Hijyen4 & ,796 & & \\
\hline & & Hijyen5 & ,765 & & \\
\hline & & Hijyen6 & 823 & & \\
\hline & & Hijyen7 &, 847 & & \\
\hline & & Hijyen8 &, 849 & & \\
\hline & & Hijyen9 & ,791 & & \\
\hline & & Hijyen10 & ,762 & & \\
\hline & & Hijyen 11 &, 745 & & \\
\hline & & Hijyen12 & 912 & & \\
\hline & & Hijyen13 & ,951 & & \\
\hline & & Hijyen14 & ,921 & & \\
\hline & & Hijyen15 & 934 & & \\
\hline & Personel Hijyeni & Hijyen16 & ,784 & & \\
\hline & & Hijyen17 & 846 & & 0,905 \\
\hline & & Hijyen18 & ,753 & & Sig., 000 \\
\hline & & Hijyen19 & 871 & & \\
\hline & & Hijyen20 & ,916 & & \\
\hline & & Hijyen21 & ,752 & & \\
\hline & & Hijyen22 & ,763 & & \\
\hline & & Hijyen23 & ,768 & & \\
\hline & & Hijyen 24 & ,743 & & \\
\hline & Kullanilan & Hijyen 25 & 856 & & \\
\hline & $\begin{array}{c}\text { Malzeme } \\
\text { Hiiveni }\end{array}$ & Hijyen26 & ,918 & & \\
\hline & & Hijyen 27 & ,712 & & \\
\hline & & Hijyen 28 & 863 & & \\
\hline & & Hijyen29 & 841 & & \\
\hline & & Hijyen 30 &, 768 & & \\
\hline & & Hijyen31 & ,771 & & \\
\hline & Yiyecek-İçecek & Hijyen 32 &, 542 & & \\
\hline & (Ürün) Hijyeni & Hijyen33 & ,735 & & \\
\hline & & Hijyen34 &, 856 & & \\
\hline
\end{tabular}




\begin{tabular}{lll}
\hline & Hijyen35 &, 826 \\
Hijyen36 &, 795 \\
Hijyen37 &, 847 \\
\hline
\end{tabular}

Tablo 2'de görüldüğü üzere kurumsal itibar ölçeğinin 20 ifade ve 6 faktörden oluşmaktadır. Kurumsal itibar ölçeğine ait KMO testi sonucu $0,867^{\prime}$ dir. Bu sonuca göre örnekleme yeterliliğinin çok iyi düzeyde olduğu söylenebilir (Karagöz, 2017: 404). Diğer taraftan Kurumsal itibar ölçeğine ait Barlett testi sonucu $\mathrm{p}(\mathrm{sig})=0,000$ 'dır. Bu sonuca göre değişkenler arasında yüksek korelasyon mevcuttur ve veriler çoklu normal dağılımdan gelmiştir (Karagöz, 2017: 408). Kurumsal imaj ölçeği ise 6 ifade ve 1 faktörden oluşmaktadır. Kurumsal imaj ölçeğine ait KMO testi sonucu 0,895 'dir. Bu sonuca göre örnekleme yeterliliğinin çok iyi düzeyde olduğu söylenebilir (Karagöz, 2017: 404). Diğer taraftan kurumsal imaj ölçeğine ait Barlett testi sonucu $p(s i g)=0,000$ 'dır. Bu sonuca göre ifadeler arasında yüksek korelasyon mevcuttur ve veriler çoklu normal dağılımdan gelmiştir (Karagöz, 2017: 408). Hijyen koşulları ölçeği 37 ifade ve 4 faktörden oluşmaktadır. Hijyen koşulları ölçeğine ait KMO testi sonucu 0,905 'dir. Bu sonuca göre örnekleme yeterliliğinin çok iyi düzeyde olduğu söylenebilir (Karagöz, 2017: 404). Diğer taraftan hijyen koşulları ölçeğine ait Barlett testi sonucu p $(\mathrm{sig})=0,000^{\prime}$ dır. Bu sonuca göre değişkenler arasında yüksek korelasyon mevcuttur ve veriler çoklu normal dağılımdan gelmiştir (Karagöz, 2017: 408). Bu sonuçlar elde edilen verilerin yapılmak istenilen analize uygun olduğunu göstermektedir.

Tablo 3. Doğrulayıcı Faktör Analizi Sonucunda Elde Edilen Uyum İyiliği Değerleri

\begin{tabular}{cccccc}
\hline & & \multicolumn{3}{c}{ Ölçeklerin Uyum İyiliği Değerleri } \\
\cline { 3 - 6 } İndeks & İyi Uyum & Kabul Edilebilir Uyum & $\begin{array}{c}\text { Kurumsal } \\
\text { İtibar }\end{array}$ & $\begin{array}{c}\text { Kurumsal } \\
\text { İmaj }\end{array}$ & $\begin{array}{c}\text { Hijyen } \\
\text { Koşulları }\end{array}$ \\
\hline $\mathbf{X}^{2} / \mathbf{d f}$ & $<3$ & $3<\left(\mathrm{X}^{2} / \mathrm{df}\right)<5$ & 2,664 & 3,211 & 3,217 \\
\hline CFI & $>.95$ & $>.90$ & 0,974 & 0,986 & 0,962 \\
\hline SRMR & $<.05$ & $<.08$ & 0,015 & 0,031 & 0,024 \\
\hline RMSEA & $<.05$ & $<.08$ & 0,021 & 0,014 & 0,36 \\
\hline
\end{tabular}

Tablo 3'te görüldügü üzere araştırmada kullanılan ölçeklere ait uyum iyiliği bulguları kabul edilebilir aralıklar içerisindedir. Bu sonuçlar doğrultusunda araştırmada kullanılan ölçeklerin verilerle doğrulandığını söyleyebiliriz. Bulgulara göre araştırmada kullanılan ölçeklerin doğrulandığı tespit edilmiştir. Bu sonuçlar kurumsal itibar ölçeğinin 6 faktörlü, kurumsal imaj ölçeğinin 1 faktörlü ve hijyen koşullarının 4 faktörlü kuramsal yapısını doğrulamaktadır.

Doğrulayıcı faktör analizi sonrasında, araştırma kapsamında oluşturulan hipotezlerin test edilmesi aşamasına geçilmiştir. Araştırmanın hipotezlerinin test edilmesi için Process Makro kullanılmıştır. Araştırma sürecinde toplanan verilerin normal dağılım göstermesi nedeniyle Maximum Likelihood yöntemi kullanılarak kovaryans matrisi oluşturulmuştur. Daha sonra kurumsal itibar, hijyen koşulları ve kurumsal imaj değişkenlerinin oluşturduğu model test edilmiştir. Yapılan test sonucunda uyum iyiliği değerlerinin ölçüm modelini doğruladığı belirlenmiştir.

Yiyecek-içecek işletmelerinin müşterilerinin işletmelere ilişkin kurumsal itibar algı düzeylerinin kurumsal imaj algıları üzerindeki etkisinde hijyen koşullarının aracı rolünün var olup olmadığını tespit etmek için bootstrap yöntemi kullanılmıştır. Bootsrap yöntemi kullanılarak regresyon analizi yapılmıştır. Bootstrap yönteminin kullanıma nedeni, Baron ve Kenny'nin geleneksel yönteminden ve Sobel analizinden daha güvenilir sonuçlar verdiğinin belirtilmesidir (Gürbüz, 
2019: 65). Araştırma sürecinde yapılan analizlerde process makro uygulaması kullanılmıştır. Bootstrap tekniği kapsamında 5000 yeniden örneklem tekniği seçilmiştir. Bootstrap tekniğinin uygulanması için asgari şart olan, değişkenlerin \%95 güven aralığında alacakları değerlerin (0) değerini (Gürbüz, 2019: 65) almamaları şartı sağlanmıştır. Bu şarta ilişkin yapılan regresyon analizi sonuçları Tablo 4'te verilmiştir. Araştırma kapsamında ulaşılan müşterilerin kurumsal itibar algılarının, kurumsal imaj algıları üzerinde dolaylı etkisinin olup olmadığı bootstrap tekniği kullanılarak elde edilen güven aralıklarına göre tespit edilmiştir. Analiz sonuçları doğrultusunda, yiyecek-içecek işletmeleri müşterilerinin kurumsal itibar algılarının, söz konusu işletmelerinin kurumsal imajları üzerinde dolaylı ve anlamlı etkiye sahip olduğu tespit edilmiştir. Tespit edilen dolaylı etkide müşterilerin hijyen koşulları algılarının, kurumsal itibar ve işletme imajı arasındaki ilişkiye aracılık ettiği tespit edilmiştir ( $\beta=, 116, \% 95$, BCA CI $[.2517, .1664])$. Aracılık etkisine ilişkin sonuçlara bakıldığında, düzleştirilmiş yanlılık ve hızlandırılmış güven değeri aralığı sonuçları (BCA CI) 0 (sıfır) değerini almamıştır. Diğer taraftan aracılık etkisinin tam standardize etki büyüklügünün $\left(\mathrm{K}^{2}\right)$ 0,92 olduğu tespit edilmiştir. Tam standardize etki büyüklüğü orta değere yakındır.

Tablo 4. Aracılık Testine İlişkin Regresyon Analizi Sonuçları (N:527)

\begin{tabular}{|c|c|c|c|c|c|c|}
\hline & \multicolumn{6}{|c|}{ Sonuç Değişkenleri } \\
\hline & \multicolumn{3}{|c|}{ Hijyen Koşulları Algısı } & \multicolumn{3}{|c|}{ Kurumsal İmaj } \\
\hline Tahmin Değişkeni & & $\beta$ & S. H. & & $\beta$ & S.H. \\
\hline Kurumsal İtibar & $\mathrm{a}$ & $241^{* * *}$ & ,054 & $\mathrm{c}^{\prime}$ & , 456 & ,114 \\
\hline Hijyen Koşulları Algısı & - & - & - & $\mathrm{b}$ & $382 * * *$ & 121 \\
\hline \multirow{3}{*}{ Sabit } & $\dot{I}_{h k}$ & 3,475 & , 167 & $\dot{\mathrm{I}}_{\mathrm{ki}}$ & 5,843 & ,423 \\
\hline & \multicolumn{6}{|c|}{ Dolaylı etki: ,116, \%95, CI [ .25, .16 ] } \\
\hline & \multicolumn{6}{|c|}{ Toplam etki: ,572, $\mathrm{p}>, 05$} \\
\hline
\end{tabular}

Not: ${ }^{* * *} \mathrm{p}<0,001$; S.H.: Standart Hata, Standardize edilmemiş beta katsayıları $(\beta)$ raporlanmıştır.

Yukarıdaki analiz sonuçlarından hareketler araştırma kapsamında oluşturulmuş olan; "H1: Müşterilerin yiyecek-içecek işletmelerinin kurumsal itibarlarına ilişkin algı düzeylerinin, işletme imajı algıları üzerinde etkisi vardır.", "H2: Müşterilerin yiyecek-içecek işletmelerine ilişkin kurumsal itibar algı düzeylerinin, müşterilerin işletmelerin hijyen koşullarına ilişkin algı düzeyleri üzerinde etkisi vardır.", "H3: Müşterilerin yiyecek işletmelerinin hijyen koşullarına ilişkin algılarının işletmelerin imajları üzerinde etkisi vardır." Ve "H4: Müşterilerin yiyecek-içecek işletmelerine ilişkin kurumsal itibar algı düzeylerinin, müşterilerin işletmeye ilişkin imaj algıları üzerinde etkisinde hijyen koşullarının aracı rolü vardır." hipotezleri kabul edilmiştir.

\section{SONUÇ ve ÖNERILER}

Yiyecek-içecek işletmeleri için kurumsal itibar müşterilerin güveninin sağlanmasında önemli rol oynamaktadır denilebilir. Çünkü yiyecek-içecek işletmelerinin uzun bir dönemde yapmış olduklarının sonucu olarak kurumsal itibarları oluşur. Yiyecek-içecek işletmelerinin kurumsal itibarlarına ilişkin müşterilerde olumlu algının oluşması işletmeye birçok avantaj kazandırabilir. Nitekim kısa sürede oluşan işletme imajı olumsuzluklardan çok çabuk etkilenebilir. Ancak kurumsal imaj algısı olumlu olan işletmelerde kurumsal imajın olumsuzluklardan daha düşük düzeyde etkilendiği söylenebilir. Bu doğrultuda hijyen koşullarının ön plana çıtığı günümüzde hijyen koşullarında yaşanabilecek olumsuzlukların işletme imajını olumsuz etkilememesi için 
kurumsal itibar daha da önemli bir rol üstlenmektedir. Araştırma kapsamında yapılan analizler sonucunda elde edilen bulgularda bu düşünceyi desteklemektedir.

Araştırma kapsamında elde edilen bulgular doğrultusunda, katılımcıların çoğunluğunun erkek olduğu görülmüştür. Bu sonuçlara göre erkeklerin dışarda daha fazla yemek yedikleri tespitinde bulunulabilir. Nitekim Türkiye'de erkeklerin bireysel olarak daha fazla yiyecek-içecek işletmelere gittikleri söylenebilir. Kadınların genellikle daha üst düzey yiyecek-içecek işletmelerine bireysel olarak gidebildiklerini söyleyebiliriz. Erkeklerin ise her düzeydeki yiyecekiçecek işletmelerine bireysel olarak gidebildikleri gözlemlenebilir. Ayrıca araştırma kapsamında oluşturulan anket formunu doldurma konusunda kadınların daha az katılım gösterdikleri de varsayılabilir. Ancak genel olarak erkeklerin yiyecek-içecek işletmelerinden daha sık hizmet aldıkları da söylenebilir. Ayrıca araştırma bulguları doğrultusunda evli insanlarında yiyecekiçecek işletmelerinde daha fazla hizmet aldıkları tespit edilmiştir. Bu sonuç araştırmanın genellikle alakart hizmet sunan yiyecek-içecek işletmelerinde anket formunun doldurtulmuş olması ile açıklanabilir. Gençlerin ve bekar insanların genellikle fastfood tarzı hizmet veren yiyecek-içecek işletmelerini tercih etmeleri bu sonucu desteklemektedir. Katılımcıların eğitim düzeylerine ilişkin değerlendirme yapmayı gerektiren çarpıcı bir sonuç tespit edilememiştir. Araştırma kapsamında yer alan yiyecek içecek işletmelerini tercih eden kişilerin neredeyse yarısının $(47,6)$ asgari ücretin üstünde ve 5000 TL arasında gelire sahip oldukları belirlenmiştir. Bu sonuç Türkiye'deki gelir dağılımına uygundur. Türkiye'deki hanelerin büyük çoğunluğunun araştırmada ön plana çıkan 2826-5000 TL aralığında gelire sahip olduğu istatistiklerle desteklenmektedir (TÜIK, 2020). Diğer taraftan katılımcıların yaş dağılımları değerlendirildiğinde sıra dışı ve değerlendirmeye değer bir sonuç ile karşılaşılmamıştır.

Araştırmada yapılan analizler sonucunda, yiyecek-içecek işletmeleri müşterilerinin kurumsal itibar algılarının, işletme imajı algılarını etkilediği tespit edilmiştir. Araştırma sonucuna göre, yiyecek-içecek işletmelerinin kurumsal itibar düzeylerine ilişkin müşteri algı düzeyi arttıkça, müşterilerin kurumsal imaj algı düzeyleri de artmaktadır. Yiyecek-içecek işletmeleri müşterilerinin kurumsal itibar alg1 düzeylerinde oluşacak artış, söz konusu işletme müşterilerinin işletme imajı algı düzeylerinin artmasını sağlayacaktır. Diğer taraftan, söz konusu müşterilerin kurumsal itibar algı düzeylerinde yaşanacak düşüş ise işletme imajı algı düzeyinde de düşüşe neden olacaktır. Araştırma sonucunda ulaşılan sonuçlar, teoride yer alan genel görüşü desteklemektedir (Han vd., 2015: 84; Potgieter ve Doubell, 2020: 107). Uzun bir süreç içerisinde, işletmenin faaliyetlerinin müşteriler tarafından değerlendirilmesi sonucunda oluşan kurumsal itibar, kısa süre içerisinde oluşan ve olumlu ve olumsuz durumlardan hızlı şekilde etkilenen kurumsal imajı, etkiliyor olması beklenilen bir sonuçtur.

Araştırma sürecinde elde edilen verilerin analizi sonucunda, yiyecek-içecek işletmelerinden hizmet alan müşterilerin kurumsal itibar algı düzeylilerinin işletmelerin hijyen koşullarına ilişkin algılarını etkilediği tespit edilmiştir. Müşterilerin kurumsal itibar algı düzeyleri arttıkça, işletmelerin hijyen koşullarına ilişkin algı düzeyleri de olumlu yönde artmaktadır. Tam tersi durumda ise müşterilerin kurumsal itibar algı düzeylerinde düşüş yaşandığında, müşterilerin işletmenin hijyen koşullarına ilişkin olumsuz alg1 düzeylerinin arttığı görülmüştür. Bu sonuç teoride yer alan bilgileri desteklemektedir (Jim ve Leslie, 2009: 247; Läikkö-Roto ve Nevas, 2014: 65) Kurumsal itibar bileşenlerinin hijyen koşullarını da içeriyor olması, kurumsal itibara yönelik faaliyetlerin hijyen koşullarında iyileşmelere yol açmasını sağlayabilir. Ayrıca kurumsal itibar uzun bir süreç içerisinde oluştuğu için, olumlu kurumsal itibar algısı müşterilerin hijyen koşullarında yaşanan olumsuzlukları süreklilik arz etmemesi durumda göz ardı etmelerine neden olabilir. Müş̧eriler hijyen koşullarında yaşanan olumsuzlukları, zihinlerindeki kurumsal itibar algısı doğrultusunda değerlendirebilirler. Bu doğrultuda hijyen koşullarında çok büyük olumsuzluklar olmadığı sürece ve süreklilik arz etmediği sürece hijyen koşullarındaki 
olumsuzluklara karşı müşteriler tarafından tolerans gösterilebilir. Ancak burada zincirleme bir ilişkiden de bahsedilebilir. Çünkü kurumsal itibar bileşenleri, hijyen koşullarına ilişkin faaliyetleri içerir, hijyen koşulları da kurumsal itibar için gereklidir. Bu nedenle kurumsal itibar, yiyecek-içecek işletmelerine hijyen koşullarında yaşanabilecek olumsuzlukların yansımalarını, azaltma konusunda yardımcı olmaktadır çıkarımı yapılabilir.

Diğer taraftan yiyecek işletmelerinde hijyen koşulları, müşterilerin işletmeyi tercihlerinde önemli bir rol oynamaktadır. Bu doğrultuda yiyecek-içecek işletmeleri müşterilerinin işletmeye ilişkin imaj algılarını şekillendirirlerken, hijyen koşullarını dikkate aldıkları söylenebilir. Araştırma sonucunda yukarıda belirtilen ifadenin desteklendiği görülmüştür. Araştırma sonucunda müşterilerin hijyen koşullarına ilişkin algılarının, yiyecek içecek işletmelerinin imajlarına ilişkin algılarını etkilediği tespit edilmiştir. Bu doğrultuda müşterilerin hijyen koşullarına ilişkin olumlu algı düzeyleri arttıkça işletmenin imajına ilişkin algıları da olumlu yönde artış göstermektedir. Diğer taraftan müşterilerin hijyen koşullarına ilişkin olumsuz algı düzeyleri arttıkça da işletmeye ilişkin imaj algılarının olumsuz yönde artış gösterdiği tespit edilmiştir. Söz konusu sonuçlar teoride yer alan bilgileri desteklemektedir (Jin ve Leslie, 2009: 247; Läikkö-Roto ve Nevas, 2014: 65). Kısa sürede oluşan ve olumsuz veya olumlu faktörlerden hızlı şekilde etkilenen işletme imajının hijyen koşullarından olumlu veya olumsuz etkilenmesi beklenilen bir sonuçtur.

Yukarıda yer verilen sonuçlar kurumsal itibar ve hijyen faktörlerinin ayrı ayrı işletme imajı üzerinde etkili olduğunu göstermektedir. Ancak araştırmanın temelini oluşturan, kurumsal itibar ve işletme imajı arasındaki ilişkide hijyen koşullarının aracı etkisi, bu çalışma için önemli bir yere sahiptir. Araştırma sürecinde yapılan analizler sonucunda müşterilerin kurumsal itibar algılarının, işletme imajı üzerindeki etkisinde, hijyen koşullarına ilişkin algılarının aracı etkisinin olduğu tespit edilmiştir. Konuyla ilgili daha önce yapılmış çalışmalar incelendiğinde, hijyen koşullarının kurumsal itibar ve işletme imajı ilişkisindeki aracı rolünü ele alan bir çalışmaya rastlanmamıştır. Ancak burada ortaya çıkan hijyen koşullarının aracı rolünün varlığı, teorik olarak beklenen bir sonuçtur. Çünkü dolaylı etki değeri (,116), iki müşteriden kurumsal itibar algı düzeyi, diğer müşteriden bir birim yüksek olan müşterinin, hijyen koşullarını olumlu algılama düzeyi, kurumsal itibar alg1 düzeyi düşük olan müşteriden, daha yüksek olacağı için, işletme imajı algı düzeyinin ,116 birim daha yüksek olmasını sağlamaktadır. Bu sonuca göre kurumsal itibar algı düzeyi yüksek olan müşteriler hijyen koşullarına ilişkin olumlu algı geliştirmektedir. Kurumsal itibar vasıtasıyla gelişen olumlu hijyen koşulları algısı ise müşterilerin zihinde işletme ile ilgili olumlu imaj oluşmasını sağlamaktadır. Belirtildiği üzere yiyecek-içecek işletmeleri müşterilerinin kurumsal itibar algı düzeylerinin, işletme imajı algıları üzerinde etkisinde hijyen koşullarının etkisi bulunmaktadır.

$\mathrm{Bu}$ çalışmada elde edilen sonuçlardan hareketle yiyecek-içecek işletmeleri yöneticilerine ve araştırmacılara bazı önerilerde bulunulabilir. Yiyecek-içecek işletmeleri yöneticiler için, işletmelerinin kurumsal itibarlarını geliştirmeleri, kurumsal itibar ile ilgili faaliyetlere önem vermeleri önerilebilir. Çünkü kurumsal itibar sayesinde yaşanabilecek olumsuzluklar müşteriler tarafından makul karşılanabilmektedir. Böylelikle müşteriler işletme imajı algısı geliştirirken olumsuzluklardan daha az etkilenmektelerdir. Böylelikle işletmelere karşı daha olumlu algılara geliştirebilmektelerdir. Kurumsal itibar uzun bir süreçte ortaya çıtığı için, işletme imajında yaşanabilecek ani değişimlerin önüne geçme rolüne sahip olabilmektedir. Bu nedenle işletme yöneticileri kurumsal itibarın öneminin farkına varmalılardır.

Ayrıca araştırma sonucunda, hijyen koşullarının müşterilerin, yiyecek-içecek işletmelerine ilişkin imaj algıları üzerinde etkili olduğu tespit edilmiştir. Bu doğrultuda yiyecek-içecek işletmeleri yöneticilerine, işletmelerinde hijyen koşullarını en azından asgari düzeyde sağlamaları önerilebilir. Ancak hijyen koşullarında yaşanacak iyileştirmelerin, müşterilerin işletme imajlarına ilişkin algılarının iyileşmesini sağlayacağı gözden kaçırılmamalıdır. Burada yiyecek içecek 
işletmeleri yöneticilerinin, asgari hijyen koşullarını sağlama ile yetinmemeleri ve hijyen koşullarına geçmişe nazaran daha fazla önem vermeleri önerilmektedir.

Ayrıca bu araştırma sonuçları doğrultusunda, yiyecek-içecek işletmeleri yöneticileri iş modellerinde hijyen koşullarının rolünü gözden geçirebilirler. Uygulamış oldukları iş modelinde hijyen koşullarının önem düzeyi değerlendirilerek, değişen çevre koşullarına uygun olarak hijyen koşullarının önem düzeyinde düzenlemeler yapmaları önerilmektedir.

Diğer taraftan araştırmacılara, bu çalışma covid-19 salgını döneminde yapıldığı için, covid-19 salgını son bulduktan sonra benzer bir araştırma yapmaları ve bu araştırmanın sonuçları ile salgın sonrası yapılacak araştırmanın sonuçlarını karşılaştırmaları önerilebilir. Böylelikle müşterilerin algılarında covid-19 salgın sürecinin etkili olup olmadığı da belirlenebilir. Ayrıca bu araştırmada kullanılan modele farklı değişkenleri dâhil etmeleri önerilebilir. Örneğin kurumsal itibarın bileşenleri arasında yer alan ve müşterilere yönelik olan sosyal sorumluk ve kurumsal çekicilik değişkenleri araştırma modeline dâhil edilebilir. Diğer taraftan araştırma modeli kullanılarak farklı işletmeler ile yiyecek-içecek işletmelerinin karşılaştırılması yapılabilir. Böylelikle hijyen koşullarının, işletme imajı üzerine etkisinin sadece yiyecek-içecek işletmeleri ile sinırlı olup olmadığı tespit edilebilir.

\section{KAYNAKÇA}

Agarwal, J., Osiyevskyy, O., and Feldman, P. M. (2015). Corporate reputation measurement: Alternative factor structures, nomological validity, and organizational outcomes. Journal of Business Ethics, 130(2), 485-506.

Akdu, S. (2017). Turizm sektöründe hizmet hatası telafi stratejileri, hizmet kalitesi algisı ve kurumsal imaj algısı arasındaki ilişkiye yönelik bir araştırma, Gümüşhane Üniversitesi Sosyal Bilimler Enstitüsü, İşletme Anabilim Dalı, Gümüşhane.

Alrubaiee, L. S., Aladwan, S., Joma, M. H. A., Idris, W. M., and Khater, S. (2017). Relationship Between Corporate Social Responsibility and Marketing Performance: The Mediating Effect of Customer Value and Corporate Image. International Business Research, 10(2), 104-123.

Amini, A., Darani, M., Afshani, M., and Amini, Z. (2012). Effectiveness of marketing strategies and corporate image on brand equity as a sustainable competitive advantage. International Journal of Contemporary Research in Business, 4 (2), 192-205.

Andreassen, T.W., and Lindestad, B., (1998). The effect of corporate image in the formation of customer loyalty. Journal of Service Research, 1 (1),82-92.

Barnett, M. L., Jermier, J. M., and Lafferty, B. A. (2006). Corporate reputation: The definitional landscape. Corporate Reputation Review, 9(1), 26-38. http://dx.doi.org/10.1057/ palgrave.crr.1550012.

Baygül Özpınar Ş. B. (2008). Kurumsal itibarın ölçümü: Türkiye'ye yönelik ölçek geliştirme çalışması, Anadolu Üniversitesi Sosyal Bilimler Enstitüsü, Reklamcılık ve Halkla İlişkiler Anabilim Dalı, Eskişehir.

Büyüköztürk, Ş. (2010). Sosyal Bilimler İçin Veri Analizi El Kitabı. (12. Basım). Ankara: Pegem Yayınları.

Can, A. (2019). SPSS ile Bilimsel Araştırma Sürecinde Nicel Veri Analizi. (7.Basım). Ankara: Pegem Akademi. 
Chang, K. C. (2013). How reputation creates loyalty in the restaurant sector. International Journal of Contemporary Hospitality Management, 25(4), 1-25. http://dx.doi.org/10. 1108/09596111311322916.

Chun, R. (2005). Corporate reputation: Meaning and measurement. International journal of management reviews, 7(2), 91-109.

Denizer, D. (2003). Otel işletmelerinde ziyafet menülerinin planlaması üzerine kavramsal bir irdeleme. Anatolia: Turizm Araştırmaları Dergisi, 14 (1), 33-44.

Dichter, E. (1985). What's in an image? Journal of Consumer Marketing, 2(1), 75-81.

Dowling, G. R. (1986). Managing Your Corporate Image, Industrial Marketing Management, 15, 109115.

Fombrun, C. J., Gardberg, N. A., and Sever, J. M. (2000). The reputation quotient SM: A multistakeholder measure of corporate reputation. Journal of Brand Management, 7(4), 241-255. https://doi.org/10.1057/bm.2000.10

Gliner, A. J., Morgan, A. G. and Leech, L. N. (2015). Uygulamada Araştırma Yöntemleri: Desen ve Analizi Bütünleştiren Yaklaşım. (Çev: V. Bayar ve S. A. Bayar). Ankara: Nobel Yayınevi.

Gray, E. R., and Balmer, J. M. (1998). Managing Corporate Image and Corporate Reputation. Long Range Planning, 31(5), 695-702.

Han, S. H., Nguyen, B., and Lee, T. J. (2015). Consumer-based chain restaurant brand equity, brand reputation, and brand trust. International Journal of Hospitality Management, 50, 84-93.

Ho, D. E., Ashwood, Z. C., and Handan-Nader, C. (2017). The false promise of simple information disclosure: New evidence on restaurant hygiene grading. Unpublished manuscript, Stanford University. September, 1-80.

Howard, S. (1998). Corporate Image Management: A Marketing Discipline for the 21st Century. Butterworth-Heinemann Asia.

Hu, H. S., Lai, S. H., and King, B. (2020). Restaurant employee service sabotage and customer deviant behaviors: the moderating role of corporate reputation. Journal of Hospitality $\mathcal{E}$ Tourism Research, 44(7), 1126-1152.

Islam, T., Islam, R., Pitafi, A. H., Xiaobei, L., Rehmani, M., Irfan, M., and Mubarak, M. S. (2021). The impact of corporate social responsibility on customer loyalty: The mediating role of corporate reputation, customer satisfaction, and trust. Sustainable Production and Consumption, 25, 123-135.

Javed, M., Rashid, M. A., Hussain, G., and Ali, H. Y. (2020). The effects of corporate social responsibility on corporate reputation and firm financial performance: Moderating role of responsible leadership. Corporate Social Responsibility and Environmental Management, 27(3), 13951409.

Jin, G. Z., and Leslie, P. (2009). Reputational incentives for restaurant hygiene. American Economic Journal: Microeconomics, 1(1), 237-267.

Karagöz, Y. (2017). Bilimsel Araştırma ve Yayın Etiği, Ankara: Nobel Akademik Yayıncılık.

Keh, H. T., and Xie, Y. (2009). Corporate reputation and customer behavioral intentions: The roles of trust, identification and commitment. Industrial Marketing Management, 38(7), 732-742. http://dx.doi.org/10.1016/j.indmarman.2008.02.005. 
Läikkö-Roto, T., and Nevas, M. (2014). Restaurant business operators' knowledge of food hygiene and their attitudes toward official food control affect the hygiene in their restaurants. Food Control, 43, 65-73.

Nguyen, N., and Leblanc, G. (2001). Corporate image and corporate reputation in customers' retention decisions in services. Journal of retailing and Consumer Services, 8(4), 227-236.

Peltekoğlu, Filiz Balta (2012), Halkla ilişkiler nedir? İstanbul: Beta Basım Yayım Dağıtım A.Ş.,

Potgieter, A., and Doubell, M. (2020). The Influence of Employer branding and Employees' personal branding on Corporate Branding and Corporate Reputation. African Journal of Business E Economic Research, 15(2), 107-133.

Sánchez-Torné, I., Morán-Álvarez, J. C., and Pérez-López, J. A. (2020). The importance of corporate social responsibility in achieving high corporate reputation. Corporate Social Responsibility and Environmental Management, 27(6), 2692-2700.

Schmitt, B.H., Simonson, A., and Marcus, J. (1995). Managing corporate image and identity. Long Range Planning 28 (5), 82\}92.

Singh, K., and Misra, M. (2021). Linking corporate social responsibility (CSR) and organizational performance: The moderating effect of corporate reputation. European Research on Management and Business Economics, 27(1), 100139.

Soylu, A., and Taştan, H. (2020). Algılanan Restoran Temizliğinin Müşteri Tatminine Etkisi. Gastroia: Journal of Gastronomy and Travel Research, 4 (1), 86-105. DOI: 10.32958/gastoria.688514.

Sökmen, A. (2001). Konaklama ve yiyecek içecek işletmelerinde servis tekniği ve uygulamaları. Ankara: Detay Yayıncilık.

TÜIK, (2020). Haber Bülteni, https://data.tuik.gov.tr/Bulten/Index?p=Income-and-LivingConditions-Survey-2019-33820.

Walsh, G., and Beatty, S. E. (2007). Customer-based corporate reputation of a service firm: Scale development and validation, Journal of the Academy of Marketing Science, 35(1), 127-143. http://dx.doi.org/10.1007/s11747-007-0015-7.

Walsh, G., Dinnie, K., and Wiedmann, K. (2006). How do corporate reputation and customer satisfaction impact customer defection? A study of private energy customers in Germany, Journal of Services Marketing, 20(6), 412-420. http://dx.doi.org/10.1108/ 08876040610691301.

Walsh, G., Mitchell, V. W., Jackson, P., and Beatty, S. E. (2009). Examining the antecedents and consequences of corporate reputation: A customer perspective, British Journal of Management, 20(2), 187-203. http://dx.doi.org/10.1111/j.1467-8551.2007.00557.x 